\title{
KARAKTERISTIK KEKERASAN SEKSUAL TERHADAP ANAK PEREMPUAN DI WONOGIRI DAN BOYOLALI
}

\author{
Joko Suwandi, Chusniatun, Kuswardani \\ Universitas Muhammadiyah Surakarta \\ e-mail:js171@ums.ac.id
}

\begin{abstract}
The future of this nation depends on the quality of its young generation. Sexual violence against daughters that is rampant today can damage the growth of the spiritual and physical body of the young generation. For this reason, a preventive solution is needed for prevention. This initial study will identify the characteristics of sexual violence against girls which occur in two regions, namely Wonogiri and Boyolali. This research was the qualitative descriptive analytic study that explored and described the characteristics of sexual violence against girls in the two regions. Data was collected through in-depth interviews and document review of key informants, PPA Polres officers, Head of P2TP3A, Head of Women and Children Protection, Solopos.com news and Kompasanda.com, and other key informants. Data were analysed using GAP techniques to obtain insightful initial data. The research conclusion is as follows. a) Most intrafamilial abuses are carried out by stepfather, biological father, victim's sibling and grandfather. b) Extrafamilial violence abuse is carried out by the same age victim's friends and playing that mocking the victims in abuzz and begin with alcoholic parties. The perpetrator with the status of a boyfriend is difficult to trace, and the actual cases are very large in number. c) Institutional violence abuse often occurs in elementary and junior high schools with the perpetrators is a teacher. The victims are more than one student. d) Ritualistic abuse takes the form of shamanic practices. The triggers are such as; a) inharmonious family situation, b) unfavourable economic conditions, c) unhealthy social environment, $d$ ) the negative influence of social media use, e) unstable psychological conditions, and f) superficial understanding of religion.
\end{abstract}

Keywords: Characteristics, sexual violence, girls. 


\section{PENDAHULUAN}

Indonesia benar-benar dalam keadaan darurat kekerasan terhadap anak, terutama kekerasan seksual terhadap anak-anak perempuan. Contoh kasus yang dipublikasikan oleh media masa, antalaian; perkosaan menimpa Yyn siswi SMP di Rejang Lebong Bengkulu, pada akhir April 2016 diperkosa 14 orang sebelum dibunuh. Kasus ini seakan-akan menjadi pembuka tabir cerita kasus sejenis yang lain. Di Labuhan Ratu, Lampung Timur, bocah 10 tahun diduga diperkosa dan dibunuh. Di Manado, remaja putri umur 16 tahun diperkosa 15 lelaki. Di Karawang, seorang remaja putri umur 16 tahun diperkosa lima orang. Di Cibungbulang Bogor, bocah umur 2,5 tahun diperkosa dan dibunuh. Di Aceh seorang siswi SMP diperkosa empat pria. Di Surabaya, siswi SMP diperkosa delapan remaja, dan di Klaten siswi kelas VI SD diperkosa empat ABG.

Menghitung secara pasti jumlah kasus kekerasan seksual terhadap anak perempuan, khususnya terhadap kelompok anak tidak akan mendapatkan data yang tepat, mengingat kasus semacam merupakan aib bagi si korban dan pelaku dan akan ditutup-tutupi agar tidak diketahui khalayak. Menurut Sekretaris PPPA Pusat, Pribudiarta Nur Sitepu diibaratkan 'teori gunung es', Jumlah yang terungkap dan dilaporkan kepada pihak berwajib sangat sedikit. Kasus akan dilaporkan tatkala ada pihak yang disudutkan atau dirugikan.

Berdasar catatan laporan masyarakat ke Komisi Nasional (Komnas) Perempuan, Dinas Pemberdayaan Perempuan dan Perlindungan Anak atau P2TP2A Kabupaten, PPA Polres dan laporan dari organisasi masyarakat dan lembaga lainnya, menunjukkan kasus kekerasan seksual terhadap perempuan (termasuk kelompok anak) di wilayah kita terbilang masih sangat tinggi. Komnas Perempuan dalam Siaran Pers Catatan Tahunan (Catahu) 2019 melaporkan dalam skala nasional, jumlah kasus yang terjadi di tahun 2016 tercatat 1.799 kasus, tahun 2017 naik menjadi sebanyak 2.227 kasus, dan tahun 2018 meningkat 14\% dari tahun sebelumnya menjadi 3.118 kasus. Lebih memprihatinkan adalah sangat tingginya kasus incest (seks dengan orangtua atau keluarga kandung), tahun 2018 tercatat 1071 kasus di seluruh Indonesia. Pelaku tertinggi incest adalah ayah kandung dan paman. Selain itu, Komnas Perempuan juga mencatat jumlah kekerasan seksual dalam konteks pencabulan oleh pacar jumlahnya paling banyak, yaitu 1750 (Catahu, 2019).

Di Jawa Tengah menurut penuturan Winarna, Plt Kepala Dinas Pemberdayaan Perempuan, Perlindungan Anak, Pengendalian Penduduk, dan Keluarga Berencana (DP3AKB) Provinsi Jawa Tengah pada 2017 ada 2.441 kasus kekerasan perempuan dan anak. Dari jumlah itu 1.400 merupakan kasus kekerasan anak, yang didalamnya termasuk kekerasan seksual terhadap anak perempuan. Kasus Kekerasan Anak dan Perempuan di Jateng menduduki peringkat tiga besar Nasional (Priyanto, 2018). Sedangkan untuk kasus tiap kabupaten di Jawa Tengah, Kabupaten Wonogiri dan Boyolali menduduki peringkat selanjutnya setelah Semarang dan Brebes dengan kasus terbanyak. Menurut Pendamping P2TP2A Wonogiri, Ririn Riadiningsih, dalam kurun waktu dua tahun terakhir, di Wonogiri tercatat 27 Kasus kekerasan seksual terhadap anak perempuan dengan jumlah korban 77 orang di Boyolali 39 Kasus.

Dampak kekerasan seksual terhadap anak perempuan sangat luar biasa, apalagi bagi anak-anak dibawah umur. Menurut Noviana (2015), dampak langsung 
yang dialami korban meliputi kematian, cedera fisik dan luka. Sedangkan dampak psikologis yang berupa perasaan depresi, malu, malas berkegiatan sosial, mengucilkan diri dari lingkungan, termasuk bersekolah dan sebagainya merupakan dampak jangka panjang. Dampak psikopatologi yang muncul dari korban kekerasan seksual itu di kemudian hari sangat berbahaya. Dari hasil sebuah studi yang didanai oleh USA National Institute of Drug Abuse, diperoleh data bahwa "Di antara lebih dari 1.400 perempuan dewasa korban pelecehan seksual saat masih kecil menderita ketergantungan terhadap obat terlarang, alkohol, dan mengalami gangguan kejiwaan" (Faller, Kathleen Coulborn, 2003). Masih dari hasil studi itu, perempuan yang mengalami pelecehan seksual pada masa kecil beresiko mengalami ketergantungn obat terlarang 2,83 kali lebih besar dibandingkan dengan perempuan normal.

Demikian luar biasa dampak yang harus ditanggung korban kekerasan seksual, khususnya pada anak-anak perempuan yang masih memiliki perjalanan hidup yang masih panjang. Untuk itu perlu dikaji lebih mendalam tentang karakteristik kekerasan seksual terhadap anak perempuan itu.

Kekerasan seksual terhadap anak (child sexual abuse), menurut WHO dalam Lidya (2009) merupakan tindak kriminal dan sipil di mana orang dewasa terlibat dalam aktivitas seksual dengan anak di bawah umur atau eksploitasi anak di bawah umur untuk tujuan kepuasan seksual. Lebih jelas dalam laporan World Conference (1995) di Beijing, pada butir 113 dirumuskan bahwa kekerasan terhadap anak perempuan sebagai "setiap tindakan berdasarkan gender yang menyebabkan atau dapat menyebabkan kerugian atau penderitaan fisik, seksual atau psikologis terhadap anak perempuan, termasuk ancaman untuk melakukan tindakan tersebut, pemaksaan atau perampasan kemerdekaan, baik yang terjadi dalam kehidupan masyarakat atau pribadi".

Bentuk-bentuk kekerasan seksual pada anak mencakup penganiayaan seksual secara fisik dan non fisik. Menurut Suradi (2013) kekerasan secara phisik meliputi; menyentuh atau mencium genitalia anak, penetrasi, intercource, incest, oral seks, sodomi, memaksa anak membuka pakaian dan sampai pada pemerkosaan. Sedangkan kekerasan seksual non fisik meliputi; mempertontonkan gambar, photo, video dan atau sesuatu yang mengandung unsur pornografi atau termasuk juga mempertontonkan aktivitas seksual orang serta hal yang termasuk exhibitionism, atau mengintip saat mandi (voyeurism).

Dari kasus kekerasan terhadap anak, kekerasan seksual pada anak perempuan apapun bentuknya merupakan kasus yang paling memprihatinkan dan berdampak signifikan terhadap kehidupan kedepannya, dan ini jumlah kasusnya dari tahun ketahun diprediksi semakin meningkat. Secara umum menurut Pasalbessy (2010), dampak selanjutnya dari kekerasan seksual pada anak perempuan itu antara lain; sikap menghindari hal-hal yang berhubungan dengan seksual, menolak organ reproduksi atau tubuhnya sendiri, anak sering mimpi buruk dan sulit tidur, penurunan nafsu makan, takut dan malu menjadi bagian dari keluarganya, depresi, perilaku menarik diri dari pergaulan, injury, suka menyendiri, mengeluh nyeri pada daerah kemaluan, memar dan berdarah pada daerah perineal, terlambat dalam pertumbuhan dan perkembangan dan kehamilan yang tidak diinginkan.

Untuk menyelesaikan permasalahan sosial ini perlu dilakukan upaya mendiagnosis sumber dan menentukan permasalahan sosial ini, agar jelas dan bisa 
ditemukan solusi yang tepat. Dikenal dua pendekatan untuk mendiagnosis sumber penyebab munculnya masalah sosial kekerasan seksual terhadap anak perempuan ini, yaitu person blame approach dan system blame approach (Eitzen \& Zinn, 2006: 45). Pendekatan person blame approach berasumsi bahwa sumber masalah sosial ada pada pelaku atau penyandang masalah, sehingga fokus diagnosis dan pemecahan pada latarbelakang kehidupan aktor tersebut. Pendekatan system blame approach berasumsi sumber masalah terletak pada tataran sistem, sehingga fokus diagnosis dan pemecahannya pada penanganan sistemnya. Lebih lanjut Eitzen dan Ziin menyebut 'medical model' sebagai solusinya, yaitu memecahkan masalah sosial beserta segala implikasinya sama dengan mengobati masyarakat yang sakit. Tinjauan secara social pathologist ini melihat sumber masalah adalah individu dan masyarakatnya, sehingga perilaku individu pelaku kekerasan seksual terhadap anak perempuan dianggap sebagai penyakit masyarakat yang dapat merusak sistem sosial (masyarakat).

Upaya pencegahan kasus kekerasan seksual terhadap anak perempuan harus berangkat dari kajian penyebabnya dan selanjutnya dilakukan secara preventif, kuratif dan preservatif. Empat potensi penyebab terjadi tindakan kekerasan menurut Ketua Komnas Perlindungan Anak Arits Merdeka Sirait (dalam Agustina, 2015), pertama adanya pelaku yang memiliki kesempatan, kedua, adanya korban yang kemungkinan tidak memahami masalah seks, tidak bisa menolak dan ketakutan terhadap intimidasi, ketiga, kurangnya pengawasan dari orangtua, dan keempat adanya pemicu.

Peran orang tua, sekolah dan lingkungan sangat diharapkan untuk mencegah dan mengatasi masalah ini. Peran sangat vital terletak di pundak orang tua (Margaretha, dkk, 2013). Pencegahan harus dimulai sejak dini, orangtua harus selalu memperhatikan proses tumbuh kembang putra-putrinya. "Memberi pengertian dan penjelasan kepada anak tentang bagian tubuh mana yang tidak boleh di pegang oleh orang lain merupakan salah satu hal yang bisa dilakukan untuk pencegahan dini harus dilakukan oleh orang tua dan sekolah" ujar Psikiater Anak dan Remaja Suzy Yusna Dewi.

Peran sekolah juga harus dioptimalkan. Hal yang perlu dilakukan sekolah untuk mencegah kekerasan, termasuk kekerasan seksual, menurut Swearer (2009) meliputi; pemberlakuan kebijakan sekolah yang anti kekerasan, menghidupkan budaya sekolah yang sehat dan terhindar dari kekerasan, melakukan pendampingan, dan kontrol sosial. Hal ini sesuai dengan fungsi edukasi kekerasan terhadap anak (Moore \& Minton, 2015; Fontaine, 1991), yaitu meliputi; a) menanamkan pengertian bahwa rasa aman adalah hak dan milik semua orang; b) menyadarkan semua orang di sekolah bahwa tindakan kekerasan dalam bentuk apapun tidak dapat diterima (zero tolerance); c) membantu anak mengetahui, memahami, mengenali, mengidentifikasi dan mendeskripsikan peristiwa, perilaku dan pelaku kerasan; d) membekali anak untuk membuat keputusan strategis mengenai perilaku dan peristiwa kekerasan; e) membantu anak membentuk lingkaran orang yang mereka dapat percayai untuk membantu penanggulangan kekerasan; f) menanamkan kepercayaan diri pada anak untuk terlibat dan turut serta dalam penggalangan budaya damai dan sehat. 


\section{METODE PENELITIAN}

Penelitian kualitatif jenis deskriptif analitik ini (Moleong, 2010) berusaha mengeksplorasi dan mendeskripsikan tentang karakteristik kekerasan seksual terhadap anak perempuan, di wilayah Wonogiri dan Boyolali. Data dikumpulkan melalui wawancara dan kajian dokumen secara mendalam dengan menggunakan informan kunci, meliputi; petugas PPA Polres, Kabid P2TP3A, Kasi Perlindungan Perempuan dan Anak, Berita Solopos.com dan Kompasanda.com, dan informan kunci, seperti; guru sekolah dan masyarakat. Data selanjutnya dianalisis menggunakan teknik Gender Analysis Pathway/GAP (Puspitawati, 2012) untuk diperoleh data pembuka wawasan tentang kasus kekerasan seksual di wilayah kabupaten Wonogiri dan Boyolali.

\section{HASIL PENELITIAN DAN PEMBAHASAN}

Seperti kita ketahui bersama, bahwa kasus kekerasan seksual (sexual abuse) dalam bentuk pencabulan, bagi korban dan pelaku menjadi suatu aib pribadi dan keluarga, sehingga diusahakan untuk tidak diketahui oleh khalayak, apalagi bila menimpa anak-anak perempuan. Untuk itu menghitung jumlah kejadian tindak kekerasan seksual (sexual abuse) pada anak perempuan di Wonogiri dan Boyolali hanya yang tercatat di dua lembaga yang menangani permasalahan ini, yaitu PPA dan dinas pemberdayaan perempuan dan perlindungan anak. Menurut catatan selama kurun waktu 2017-2018, di Wonogiri tercatat 27 kasus dengan jumlah korban 77 orang dan di Boyolali 39 Kasus.

Ditinjau dari hubungan korban dengan pelaku dapat dipetakan menjadi beberapa kategori, antara lain:

a. Intra Familial Abuse

Intra Familial Abuse, yaitu kekerasan seksual dilakukan oleh orang-orang yang masih memiliki hubungan darah dengan korban, atau yang merupakan bagian dalam keluarga inti dari korban, antara lain; Kakek, ayah kandung, saudara kandung dan paman. Intra familial abuse ini termasuk di dalamnya kategori incest. Tetapi dalam kajian ini intra familial abuse termasuk orang yang hidup bersama dengan korban walupun tidak memiliki hubungan darah, yaitu ayah tiri, saudara tiri dan saudara jauh yang numpang di keluarga itu.

Kasus intra familial abuse di Wonogiri yang termasuk incest sesuai data di kantor PPA, dan reportase Solopos.com (2018) selama kurun waktu 2 tahun terakhir tercatat satu kasus oleh saudara kandung, satu dicabuli paman dan satu kasus oleh kakeknya sendiri, saat sang cucu dititipkan oleh orangtuanya untuk ditinggal bekerja. Sedangkan pencabulan dilakukan oleh ayah tiri, dari rangkuman berita Solopos.com (2018) terjadi di tiga wilayah Wonogiri, yaitu di Jatipuro, Kota dan Wuryantoro. Di Jatipuro seorang anak perempuan berumur 10 tahun dicabuli oleh ayah tirinya beberapa kali, selain dicabuli ayah tirinya korban juga dicabuli oleh kakak kandungnya sendiri yang berumur 20 tahun. Kasus lain seorang remaja putri umur 14 tahun asal Wonogiri Kota menjadi korban pencabulan oleh ayah tirinya warga Bekasi yang tinggal bersamanya. Kasus yang sama terjadi di Kecamatan Wuryantoro, ayah tiri mencabuli anak tirinya beberapa kali.

Sebagian besar korban mengaku sangat terpaksa untuk melayani nafsu bejat orang yang seharusnya melindungi karena rasa takut tidak diurusi, takut kalau ibunya dicerai dan terpaksa karena 'sungkan' menolak. Para pelaku sebagian tidak 
menjanjikan sesuatu untuk merayunya, tetapi justru memberi intimidasi yang membuat si korban tidak bisa berbuat apa-apa. Ada dua korban yang mereka mau melayani karena dijanjikan sesuatu, salah satunya akan dibelikan hand phone (HP).

Berdasarkan kajian mendalam dan dimakmumi oleh petugas PPA Polres Wonogiri lebih banyak dilatarbelakangi oleh kondisi-situasi kehidupan ekonomi keluarga yang tergolong miskin. Kondisi rumah yang tidak ada kamar khusus untuk anak-anak perempuan yang beranjak dewasa, membuat korban tidur ditempat yang dapat dilihat orang lain. Ada dua pelaku yang mengatakan terangsang birahinya saat melihat korban tidur dan tersingkap bagian tubuhnya. Selain itu alasan klasik dari semua pelaku, mereka sudah lama tidak mendapat pelayanan dari ibu korban. Selain itu ada satu orang pelaku yang memang memiliki track record gonta-ganti perempuan.

Kasus intra familial abuse di Boyolali hanya ada tiga yang terungkap, yaitu kasus seorang ayah kandung tega mencabuli putrinya sendiri sampai hamil (SoloPos, 5 April 2018). Kasus yang lain menurut Kasi Perlindungan Perempuan dan Anak, terjadi pencabulan oleh ayah kandung dan kakeknya di wilayah sawit, dilakukan oleh ayah tiri, terjadi di wilayah Sawahan dan Cepogo. Sedangkan kasus pencabulan oleh saudara kandung dan paman dari korban tidak tercatat. Sehingga dari dua kabupaten ini kasus intra familial abuse kurang dari 17\%.

Latar belakang kehidupan ekonomi dan sosial keluarga korban sama dengan yang terjadi di Wonogiri. Berdasarkan penuturan Kabid P2TP3A hampir sebagian besar kasus terjadi di keluarga yang tidak mampu. Hal ini sesuai dengan statemen Cok Gede Atmadja (dalam Suda 2009), yang mangatakan pencabulan terhadap anak terjadi karena himpitan ekonomi. Kondisi rumah yang juga sama tanpa kamar khusus untuk anak perempuan, ketiadaan hiburan dan juga kurang harmonisnya hubungan suami isteri dalam rumah tangga korban dan pelaku.

Dari sisi jumlah kasus kekerasan seksual terhadap anak perempuan di dua kabupaten ini hampir sama dengan jumlah kasus di negara Amerika Utara dan India. Menurut Gorey KM, Leslie DR (1997), sekitar 15\% sampai 25\% perempuan di Amerika Utara pernah mengalami pelecehan seksual dimasa kecilnya. Dari jumlah itu 30\% dilakukan oleh keluarga dari si korban sendiri, meliputi saudara, ayah, paman atau sepupunya. Sedangkan di India seperti dipublikasikan oleh The Government of India, (Ministry of Women and Child Development) di tahun 2007, $53.22 \%$ seluruh jumlah anak-anak pernah mengalami pelecehan seksual, dari jumlah itu 47,06\% dialami oleh anak-anak perempuan. muan utama penelitian ini. Kasus terbanyak di Andhra Pradesh, Assam, Bihar dan Delhi, rata-rata 21,90\%.

\section{b. Extra Familial Abuse}

Extra Familial Abuse, yaitu kekerasan seksual dilakukan oleh orang lain di luar keluarga korban. Pada pelecehan seksual yang pelakunya orang di luar keluarga umumnya dilakukan oleh tetangga, pacar, teman sekolah, teman sepermainan dan yang sekarang berkembang teman ber-media sosial. Menurut penuturan berbagai sumber, sebenarnya data paling banyak pelakunya adalah pacar. Di Wonogiri tercatat 8 laporan pencabulan oleh pacar dan di Boyolali 10 laporan, hampir semua diselesaikan secara kekeluargaan dan tertutup kasusnya. Kecuali satu kasus di Jatisrono Wonogiri, tak terima diputus pacaran oleh korban (15 tahun), pelaku (20 tahun) menyebar video mesum mereka berdua dengan korban ke orang tua 
dan gurunya. Kasusnya akhirnya dilaporkan ke Polisi dan diproses secara hukum (Suharsih, 2019). Jumlah ini jauh dari yang sebenarnya terjadi, tetapi tidak dilaporkan kepada pihak berwenang dan kalau terungkap diselesaikan secara kekeluargaan dan kebanyakan menurut petugas di dinikahkan secara siri. Karena korban maupun pelaku belum cukup umur. Sedangkan kasus yang sampai pada petugas atau diperkarakan lebih banyak disebabkan oleh ketidak puasan pihak keluarga korban terhadap sikap para pelaku, seperti misalnya adanya pengingkaran janji dan sebagainya.

Kasus pencabulan yang membuat hati miris dilakukan seorang laki-laki dewasa usia 47 tahun terhadap tetangganya yang masih balita usia 4 tahun. Ironisnya pelaku telah melakukannya sebanyak lima kali. di lain yang dilakukan teman sebaya sering terjadi dan dilakukan secara bersama-sama oleh beberapa pria. Lebih ironis kebanyakan pelaku masih dibawah umur dan dipengaruhi oleh minuman keras. Ada tiga kasus sebagai contoh; pertama, pencabulan terhadap seorang anak perempuan di Jatiroto Wonogiri, dihari perayaan ulang tahunnya ke 16. Korban dikerjai oleh 4 remaja tetangganya. Korban dibawa ke hutan dan dicekoki miras sebelum dicabuli beramai-ramai. Kedua, di Jatisrono seorang siswi yang masih duduk di kelas 2 SMP diperkosa 3 pria, dua diantaranya pelajar SMK. Sebelum kejadian korban dicekoki minuman keras.

Kasus ketiga, remaja putri asal Wonogiri dicabuli lima remaja, di dua lokasi, yaitu lingkungan GOR Giri Mandala dan di Gardu Pandang Waduk Gajah Mungkur. Sebelumnya korban juga dicekoki miras sampai mabuk. Sedangkan kasus keempat, seorang siswi SMP umur 14 tahun, Kecamatan Kismantoro, melapor kepada pihak berwajib karena tindak perkosaan oleh seorang pemuda berusia 20 tahun yang baru dikenalnya lewat medsos. Saat ini pelaku, pemuda asal Dusun Gunung Gede, Desa Badegan, Ponorogo masih menjalani hukuman penjara.

Kasus kelima, terjadi di Slogohimo, perkosaan dilakukan oleh seorang remaja putra yang masih duduk di SMP berusia 15 tahun, terhadap tiga anak perempuan, satu berusia 4 tahun dan dua anak berusia 8 tahun. Kasus keenam, seorang remaja putra umur 16 tahun ikut bersama-sama empat remaja lainnya yang lebih tua memperkosa remaja putri usia 14 tahun di area wisata Gunung Gandul.

Dalam kasus extra familial abuse, hampir $80 \%$ pelaku pencabulan dikenal oleh korban melalui berbagai bentuk relasi, antara lain; pertemanan dalam konteks teman sekolah dan teman sosmed, sedangkan sisnya tidak di kenal karena sebagai teman dari temannya. Relasi dari persahabatan lewat sosmed inilah yang saat ini dinilai mendominasi peningkatan kasus pncabulan oleh teman sebaya. Pada beberapa kasus perkenalan melalui medsos juga melibatkan orang dewasa yang memperdaya korban dengan mengajak temu darat dan dengan bujuk rayu dan cara akhirnya terjadi pencabulan. Biasanya pelaku sudah sangat berpengalaman dan pernah melakukan beberapa kali dengan korban berbeda.

Kasus extra familial abuse di Wonogiri terjadi karena kurangnya pengawasan dan perhatian dari orang tua mereka, baik dalam pergaulan dan penggunaan medsos. Hal ini dimaklumi karena banyak korban ditinggal orang tuanya boro (merantau) ke kota-kota besar, untuk mencari nafkah. Mereka dititipkan kepada saudara dekat, seperti kakek-neneknya, paman atau saudara dekat yang lain untuk waktu yang cukup lama. Pelaku kebanyakan terpengaruh oleh tontonan dari gambar-gambar dan video porno di HP-nya. 
Kasus yang hampir sama terjadi juga di Boyolali, Extra Familial Abuse di wilayah Boyolali. Tiga remaja dari Ampel dan satu dari Musuk usia 20 tahun-an secara bergiliran mencabuli gadis usia 13 tahun di kos dan di hotel di wilayah Mojosongo. Korban mengaku baru 3 hari kenal dengan salah satu pelaku lewat medsos, dan selanjutnya diajak main di Kota Boyolali. terjadi di Klego, seorang anak perempuan berusia 12 tahun dicabuli tetangganya yang berumur 35 tahun saat ditinggal pergi orang tuanya ke pasar. Di Teras, anak usia 10 tahun dicabuli tetangganya yang sudah kakek-kakek tetangganya. Ibu korban memergoki tetangganya itu keluar dari kamar anaknya, tapi setelah anaknya (korban) ditanya 'diapakan dia' justru si anak kebingungan seperti orang linglung tidak ingat apaapa.

Di Kemusu remaja putri berusia 13 tahun dicabuli teman kerja ayahnya yang berumur 45 tahun. Pelaku memanfaatkan kedekatannya dengan mengajak jalanjalan ke kota dan selanjutnya diperdaya. Kasus terjadi di Juwangi tahun 2017, anak dari seseorang yang cukup terpandang diwilayah itu yang masih duduk di SMP mencabuli beberapa anak perempuan usia antara 5-6 tahun. Modusnya, pelaku menyuruh seorang anak laki-laki yang juga masih sekolah PAUD membawa temannya yang cewek ke pelaku dan selanjutnya dicabuli. Anak laki-laki patuh karena diancam akan dijeburkan ke jurang. Perkara ini sebenarnya akan diselesaikan secara kekeluargaan, akan tetapi menemui jalan buntu dan akhirnya sampai di PPA Polres Boyolali.

Di Ampel seorang siswa SMA dicabuli teman SMAnya dengan terlebih dahulu dicekoki miras sampai mabuk. Parahnya korban ini tidak mendapat perlindungan dan simpati dari pihak warga sekolah, bahkan menjadi bahan buly-an temanteman, yang akhirnya memaksa korban pindah kesekolah lain.

Dari berbagai kajian kasus dan modusnya, dapat dikatakan bahwa kasus tipu daya yang dilakukaan orang luar dari lingkungan keluarga kebanyakan termasuk kasus pelecehan (molester). Dimana kondisi korban terdominasi dan mengalami permasalahan dalam mengungkap kasusnya. Korban tidak berani mengungkapkan karena malu dengan lingkungannya seandainya diketahui orang lain, diancam akan dibunuh pelaku, diancam dipermalukan pelaku, dan ada yang diancam akan di keluarkan dari sekolah. Beberapa kasus memang dilakukan tanpa paksanaan dan kekerasan, yaitu dengan menggunakan manipulasi psikologis. Yaitu korban ditipudaya sehingga mengikuti keinginannya tanpa paksaan. Biasanya korban tergolong belum memahami dan mampu menilai sesuatu sebagai bentuk tipu daya atau bukan.

c. Ritualistic abuse

Untuk kasus tipudaya orang yang mengaku orang pintar atau dalam istilah umum disebut 'dukun cabul' dilaporkan terjadi hanya di Wonogiri. Seorang pelajar putri berusia 15 tahun diperdaya dukun cabul dengan berkedok praktik pengobatan. Dengan alasan ritual penyembuhan yang harus dilakukan, korban dicabuli dukun tersebut.

d. Institusional abuse

Solopos.com memberitakan Seorang guru olahraga di SD wilayah Girimarto Wonogiri berusia 48 tahun mencabuli 33 muridnya dalam kurun waktu 2016- 
2017. Modusnya menggunakan alasan praktik olahraga. Hal yang sama dilaporkan Soewanto, (2016) terjadi di SDN di Baturetno, seorang guru diberitakan mencabuli hampir seluruh siswa dalam satu kelas. Kasus pencabulan oleh guru terjadi di lingkungan SMPN di Slogohimo, guru bahasa Inggris pindahan dari SMPN di wilayah Puhpelem mengulang tindakan tak senonoh lagi terhadap siswi-siswinya (kumparan.com.2019)

Di Desa Manggis Kecamatan Mojosongo, Boyolali terjadi pencabulan yang melibatkan seorang pengasuh Ponpes terhadap dua orang santriwati yang masih berusia 16 tahun yang sudah berlangsung bertahun-tahun (Wardoyo, 2019).

Di dua Kabupaten yang kasus pelakunya orang dewasa terbilang sedikit yang paling mendominasi jumlah adalah teman sebaya dan pacar. Untuk kasus pelakunya pacar tidak dapat diungkap jumlah yang sebenarnya, hanya sedikit yang dilaporkan kepada aparat. Latar belakang pelaporan dari pihak korban disebabkan oleh kekecewakan atas pengingkaran kesepakatan bersama atau sikap tidak peduli pelaku dan keluarganya. Di Wonogiri tercatat 13 kasus dan di Boyolali 10 Kasus. Sedangkan kasus pencabulan oleh teman korban di Wonogiri 11 kasus dengan jumlah pelaku sangat banyak sebagian besar pelakunya lebih dari 1 orang (keroyokan). Di Jatiroto jumlah pelaku empat orang, di Wonogiri kota 5 orang, dan di Jatipuro jumlah pelaku empat orang. Di Boyolali mencapai 19 kasus. Kejadian selalu diawali dengan pesta miras, sehingga si korban mabuk dan tak sadar diri baru dikerjai.

Berdasar kajian data yang terkumpul, dapat disimpulkan beberapa faktor pemicu atau penyebab terjadinya kekerasan seksual terhadap anak perempuan dapat dikelompokkan sebagai berikut:

a. Hubungan dalam Keluarga

Hubungan keluarga yang kurangnya keharmoni disinyalir menjadi penyebab munculnya kasus kekerasan seksual terhadap anak-anak perempuan. Para pelaku intra familial abuse kebanyakan mengaku tidak mendapat pelayanan dari isteri, sehingga melampiaskan nafsu kepada anaknya. Sedangkan kasus pelaku kakak kandung dipengaruhi oleh film/ gambar porno dari internet.

Pelaku sebagai teman sebaya memiliki latar belakang beragam, kebanyakan pelaku kurang mendapat perhatian dari orang tuanya dan kurang mendapat kedamaian dirumah, namun tidak termasuk kategori broken home. Pelaku memiliki kelompok bermain sebaya yang mengarah pada kehidupan pergaulan bebas yang menyimpang dan banyak yang mengenal miras dan narkoba.

\section{b. Kondisi Ekonomi}

Menurut penuturan kasi PPA Boyolali, hampir semua korban berasal dari keluarga kurang mampu. Keinginan memiliki sesuatu dan ketidakberdayaan untuk menolak keinginan pelaku menjadi salah satu penyebab terjadinya kekerasan seksual yang sangat merugikan dirinya. Selain itu yang faktor lain yang tidak kalah urgen adalah ketiadaan kamar yang khusus untuk anak-anak perempuan yang mulai menginjak dewasa dirumah, sehingga anak-anak tidur bersama dalam ruang terbuka yang kadang-kadang posisi tidur bisa menimbulkan rangsangan birahi bagi yang melihat. 


\section{c. Lingkungan Pergaulan}

Lingkungan pergaulan merupakan faktor utama terjadinya pencabulan oleh pacar dan teman sebaya. Korban dan pelaku terpengaruh pada lingkungan pergaulan yang salah. Beberapa korban memiliki sikap perilaku 'nakal', orang jawa menyebut 'menel'. Sebagian pelaku mengaku tergiur karena sikap dan perilaku korban yang mengundang birahi. Selain itu pelaku mengaku terpengaruh miras.

\section{d. Pengaruh Teknologi dan Media Massa}

Disadari bahwa pengaruh teknologi membawa dampak positif dan negatif bagi kehidupan anak-anak dan remaja. Kecanggihan teknologi HP dan akses internet beserta aplikasinya membuka kesempatan bagi pemakai untuk bisa melihat video, gambar, tayangan dan berita yang menayangkan adegan-adegan yang kurang pantas dan melanggar susila seperti; gambar porno, adegan seks dan sebagainya yang akan ditiru oleh para remaja.

Menurut penuturan petugas PPA Polres Wonogiri, pelaku pencabulan yang berstatus pacar banyak yang mengatuhi cara-cara agar hubungan seks-nya tidak mengakibatkan hamil. Itu semua diperoleh ilmunya dari informasi dari sosmed. Selain itu keberadaan sosmed dapat dijadikan awal perkenalan dan komunikasi yang akhirnya bisa membuka peluang terjadinya kasus kekerasan seksual.

e. Kondisi Psikologi

Kondisi psikologi seseorang yang mengalami gangguan perilaku seks yang menyimpang, seperti hypersex, menjadikan pelaku mencari mangsa kepada siapapun, tidak pandang bulu korban itu siapa. Apalagi bagi yang tidak memiliki uang untuk 'jajan' diluar. Hal inilah yang disinyalir menjadi pemicu timbulnya intra familial abuse. Kondisi psikologi lain yang menjadi penyebab kekerasan seksual terhadap anak-anak perempuan adalah pedofilia, yaitu kecenderungan orang dewasa tertarik terhadap anak-anak.

f. Dangkalnya Penghayatan Agama

Dangkalnya penghayatan dan perilaku beragama menjadi salah satu pemicu timbulnya kekerasan seksual, baik itu bagi korban maupun pelaku. Rata-rata para korban dan pelaku kurang taat melaksanakan perintah agama, sehingga berani melanggar aturan agama dan berbuat dosa. Seseorang yang taat beragama, tentu akan memahami bahwa melakukan zina tidak diperbolehkan oleh agama, apalagi terhadap orang-orang yang seharusnya dilindungi.

\section{KESIMPULAN}

1. Kekerasan seksual yang termasuk intra familial abuse;

- Pelaku ayah kandung, saudara kandung, kakek dan paling banyak oleh ayah tiri.

- Alasan korban mau melayani; dipaksa, diancam sehingga takut menolak, takut tidak diurusi, takut ibunya dicerai dan diiming-imingi dibelikan HP.

- Alasan pelaku; lama tidak dilayani isteri dan terangsang posisi korban saat tidur.

- Korban kebanyakan berusia dibawah 15 tahun.

2. Kekerasan seksual yang termasuk extra familial abuse;

- Pelaku orang yang dikenal, baik teman bermain atau teman dikenal dari sosmed. 
- Pelaku tidak hanya dari golongan orang dewasa, tetapi juga melibatkan anak-anak dibawah umur.

- Pelaku lebih dari satu orang, selalu dimulai dengan berkomunikasi lewat HP dan minum-minuman keras.

- Kebanyakan korban masih usia sekolah SMP dan dinilai berperilaku 'nakal' atau menel (jawa).

3. Kasus dengan pelaku pacar diperkirakan paling banyak dari seluruh kasus kekerasan seksual terhadap anak perempuan ini yang melibatkan extra familial abuse, tetapi karena dilakukan berdasar rasa 'suka sama suka', maka jarang terungkap secara terbuka. Kasus terungkap dipublik karena ada pihak yang dikhianati atau dikecewakan. Modus minta bukti ungkapan rasa cinta dan rasa takut kalau diputus cintanya.

4. Kasus kekerasan seksual yang termasuk institusional abuse;

- Paling banyak terjadi lembaga pendidikan.

- Guru paling banyak melakukannya terhadap muridnya di satuan pendidikan SD dan SMP.

- Korban lebih dari satu siswi, bahkan bisa mencapai jumlah satu kelas.

5. Kasus kekerasan seksual yang termasuk ritualistic abuse berbentuk praktik pengobatan atau lebih tepatnya praktik perdukunan yang dilakukan oleh orangyang mengaku bisa menyembuhkan penyakit secara supranatural.

6. Faktor pemicu terjadinya kekerasan seksual terhadap anak perempuan meliputi;

- Situasi hubungan dalam keluarga yang tidak harmonis dan kurang kasih sayang.

- Kondisi ekonomi kurang baik.

- Lingkungan pergaulan yang tidak sehat dan kurangnya pengawasan orang tua.

- Pengaruh penggunaan media sosial yang salah.

- Kondisi psikologi tidak stabil.

- Dangkalnya pemahaman dan perilaku beragama.

\section{DAFTAR PUSTAKA}

Agustina, Dina. $2015 . \quad$ https:// www.cnnindonesia.com/ gayahidup/ 20151024103940-277-87009/ cara-pencegahan-dini-kekerasanseksual-pada-anak.

Catahu. 2019. https:// www.komnasperempuan.go.id/read-news-siaran-perscatatan-tahunan-catahu-komnas-perempuan-2019.

Eitzen, D. Stanley \& Zinn, Maxine Baca. 2006. Social Problems (Tenth Edition) Boston: Pearson (Allyn and Bacon).

Faller, Kathleen Coulborn. 2003. Childhood Sex Abuse Increases Risk for Drug Dependence in Adult Women. NIDA Notes, National Institute of Drug Abuse, 17 (1). National Institutes of Health. 
Fontaine, La Jeanne. 1991. Bullying: The Child View. London: Caloute Culbenkie Foundation.

Gorey KM, Leslie DR. 1997. The prevalence of child sexual abuse: integrative review adjustment for potential response and measurement biases". Child Abuse \& Neglect. $21 \quad$ (4), 391-8. doi:10.1016/ S0145-2134(96)00180-9. PMID 9134267.

Gunawan. 2017. Kekerasan perempuan dan anak jadi perhatian serius pemkab wonogiri. https:// www.fokusjateng.com/2017/07/07/.

Jurnalis Solopos. 2016. Tren kasus kekerasan seksual di wilayah soloraya terjadi pada anak usia smp. https:// news.okezone.com/read/2016/08/22/512/1469807/2016-.

Lidya. 2009. Pengaruh kekerasan pada pertumbuhan dan perkembangan anak. http:// www.perfspot.com/blogs/ blog.asp?BlogId=121153.

Margaretha, Rahmaniar Nuringtyas, \& Rani Rachim. 2013. Trauma Kekerasan Masa Kanak dan Kekerasan dalam Relasi Intim. Makara Seri Sosial Humaniora, 2013, 17(1), 33-42. DOI: 10.7454/ mssh.v17i1.1800.

Moleong, Lexy J. 2010. Metode Penelitian Kualitatif. Edisi Revisi. Bandung: Remaja Rosdakarya.

Moore, Mona. \& Minton, James Stephen. 2015. Dealing with Bullying in Schools. London: Paul Chapman Publishing.

Noviana, Ivo. 2015. Kekerasan Seksual terhadap Anak: Dampak dan Penanganannya (Child Sexual Abuse: Impact and Hendling. Sosio Informa, 01 (1), Januari - April, Tahun 2015.

Pasalbessy, Jhon D. 2010. Dampak Tindak Kekerasan Terhadap Perempuan dan Anak Serta Solusinya. Jurnal Sasi, 16 (3), Bulan Juli - September 2010.

Priyanto, Mamdukh Adi 2018. Kasus Kekerasan Anak dan Perempuan di Jateng Peringkat 3 besar di Indonesia. https:// www.msn.com/id-id/ berita/nasional.

Puspitawati, H. 2012. Gender dan Keluarga: Konsep dan Realita di Indonesia. Bogor: PT IPB Press.

SoloPos, Terbitan Kamis Kliwon 5 April 2018, Ayah Kandung Cabuli Putrinya, halaman X.

-, Terbitan Jumat Pon, 13 April 2018, Tindakan Asusila (Sepekan terjadi 3 Kasus Pencabulan), halaman IV.

Suradi. 2013. Problema dan Solusi Strategis kekerasan Terhadap Anak. Informasi Kajian Permasalahan Sosial dan Usaha Kesejahteraan Sosial, 18 (02), tahun 2013.

Soewanto, Dwi. 2016. https:// daerah.sindonews.com/read/1081946/22/ guru-sddi-wonogiri-diduga-cabuli-hampir-semua-siswanya-1454334082.

Suda, I.K, 2006. Membedah Penyebab Kekerasan Seksual terhadap Anak http:// www.dradio1034fm.or.id/ detail.php?id=4269. 
Suharsih. 2018. https:// soloraya.solopos.com/ read/20180528/495/918893/5kasus-pencabulan -paling-menggemparkan-wonogiri

Swearer, S.M., Espelage, D.L., Vaillancourt, T., \& Hymel, S. 2010. What can be done about school bullying? linking research to educational practice. Educational Research. 